\title{
Genetic structure and population dynamics of autochthonous and modern porcine breeds. Analysis of the IGF2 and MC4R genes that determine carcass characteristics
}

\author{
Silvia Llambía, María Montenegro ${ }^{a}$, Rosa Gagliardia ${ }^{a}$ Carmen Burgos $^{b}$, Jorge Hidalgo ${ }^{b}$, \\ Pascual López-Buesa ${ }^{\mathrm{b}}$, María V. Arruga ${ }^{\mathrm{c} *}$
}

\begin{abstract}
To know the genetic situation of the Pampa Rocha, Celta, Bizaro Portuguese, Duroc, Iberian Extremeño and Iberian Andalusian porcine populations, their genetic structure and population dynamics were studied on the IGF2 and $M C 4 R$ genes, which determine meat characteristics and quality. The degree of genetic variability $(\mathrm{He}=0.2511$ in Pampa Rocha; 0.0278 in Celta; 0,1453 in Bizaro Portuguese; 0.3719 in Duroc; 0.0764 in Iberian Extremeño and 0.0384 in Iberian Andalusian), genetic distance, and the presence or absence of consanguinity were studied. The Fis values were positive for the Duroc population (0.00426) indicating a very low inbreeding, the rest of the populations did not present consanguinity. Significant deviations $(P \leq 0.05)$ in the Hardy-Weinberg (HW) equilibrium were obtained for the $I G F 2$ locus in Celta, Iberian Extremeño, and Iberian Andalusian populations with the G allele fixed, while the Bizaro Portuguese, Pampa Rocha, and Duroc populations presented polymorphism, the G allelic frequency was much higher than A allele, except in the Duroc breed (0.15). These findings could help breeders to increase the presence of the A allele for the improvement of muscle mass and reduction in the back-fat thickness in this breed. All the studied populations presented polymorphism for the $M C 4 R$ locus with different frequencies for each allele. Furthermore, these results could allow developing strategies against anthropogenic activities that hinder the conservation of the biodiversity of these porcine breeds.

Key words: pig populations, $I G F 2, M C 4 R$, genes.
\end{abstract}

\section{INTRODUCTION}

The enormous scale at which porcine breeds are crossed to achieve greater production and better quality of meat has led to critical changes in the genetic structure of the various pig breeds farmed worldwide. Genetic variability has been drastically reduced and replaced by a genetic selection that seeks higher production. High rates of consanguinity, with the consequent loss of biodiversity, threaten these breeds. The knowledge of the genetics of swine breeds is important, especially for those genes that encode or regulate the traits desirable in the meat industry, as they are subject to high selection pressure (Andersson et al 1994, Azevedo et al 2015, De Campos et al 2015).

To identify the mechanisms that allow the maintenance of genetic variability, it is necessary to have suitable estimators of its magnitude, as well as to perform adequate characterisation of the patterns that are observed (Cockerham 1973). One method for the estimation of genetic variability is the use of DNA markers from each population (Avise 1994). These estimators of genetic populations allow us

Received: 04.03.2020.

Accepted: 14.08 .2020 .

aDepartment of Genetics and Animal Improvement, Faculty of Veterinary, University of the Republic, Montevideo, Uruguay.

${ }^{b}$ Department of Animal Production and Food Science, Faculty of Veterinary, University of Zaragoza, Zaragoza, Spain.

${ }^{c}$ Laboratory of Cytogenetics and Molecular Genetics, Faculty of Veterinary University of Zaragoza, Zaragoza, Spain.

*Corresponding author: MV Arruga; Miguel Servet 177, C.P. 50013, Zaragoza, Spain; mvarruga@unizar.es to determine whether genetic differences exist between two populations, identify if there is fragmentation in the population from a genetic perspective (population structure) and whether the identified variability can be explained by selection (Fisher 1930). However, in addition to selection, other effects can also affect the existing variability. For example, events that have occurred throughout history including drastic reductions in population size produced by a bottleneck such as an environmental disaster, the hunting of a species to the point of extinction, or habitat destruction that results in deaths (Fontdevila and Moya 1999). There is also the founder effect that occurs when a new population is established by a very small number of individuals from a larger population, the genetic drift that occurs when there is a change in the frequency of an existing gene variant (allele) in a population due to random sampling of organisms, and the mutations, among others. All of them can generate unexpected patterns in population parameters (Haldane 1932, Phillips et al 2019).

A population can quickly recover a high number of alleles if its structure is known and crosses are handled appropriately; however, it should be noted that if there are overlapping generations, as occurs in pig farms, the effect of the reduction of the population will be different. (Wellmann and Bennewitz 2019).

As indicated by González-Sarabia et al (2011), in some countries, such as Spain, Mexico, and Cuba, it has been observed that genetic variation in pig populations of autochthonous breeds is higher than that in commercial breeds. The autochthonous breeds are phylogenetically separated from the commercial breeds, which suggests that their genetic structures have been conserved owing to the 
lack of systematized breeding programs (Lemus-Flores $e t$ al 2001). Although no productive selection programs have been applied to these breeds, they have survived for more than 500 years and have a genetic reservoir to produce better-adapted national varieties (Lemus-Flores et al 2001).

Candidate genes associated with meat quality, such as the IGF2, MC4R genes (Fassa et al 2015), are excellent markers to identify the presence or absence of genetic variability in porcine populations.

Insulin-like factor 2 (IGF2) plays a role in muscle growth and proliferation and differentiation of myeloblasts. Van Laere et al (2003) discovered a polymorphism in the IGF2 locus, which was localised in the regulatory region of the gene. As indicated by Fassa et al (2015), the 3072 $\mathrm{G}>\mathrm{A}$ substitution in the third intron of this gene alters the binding site of a nuclear repressor by tripling the expression of mRNA in skeletal muscle during postnatal growth, when the allele A is inherited from the male parent (genomic seal). This event leads to an increase in muscle mass and reduction in the back-fat thickness (BF), but does not affect the quality of the meat (Carrodeguas et al 2005, Estellé et al 2005, Den Maagdenberg et al 2008, Oczkowicz et al 2012, Fontanesi et al 2010 and 2012, Burgos et al 2012). The authors also established the association of this polymorphism with other characteristics of economic importance, such as body weight, growth rate, and conversion efficiency. One of the main objectives of selection in pigs during the past decades has been to obtain fast-growing and lean animals. It is assumed that the rapid evolution in this direction has accompanied the selection of the beneficial allele A of the IGF2 gene in the different porcine breeds. Oczkowicz et al (2012) studied the genotype and genotypic frequencies of different breeds in Poland, reporting $100 \%$ and $91 \%$ for the AA genotype in the Duroc Jersey and Pietrain breeds, respectively, and a frequency of $27 \%$ in the local Pulawska breed.

The melanocortin 4 receptor gene $(M C 4 R)$ codes for a $\mathrm{G}$ protein transmembrane receptor with an important role in the control of energy homeostasis and is a component of the central melanocortin pathway. In mammals, this receptor is expressed mainly in the central nervous system in regions that control food consumption, body weight, and energy homeostasis (Krashes et al 2016, Shen et al 2017). In pigs, Kim et al (2000) found a missense mutation, $1426 \mathrm{~A}>\mathrm{G}$, in the sequence encoding the seventh transmembrane region of the melanocortin receptor that results in the replacement Asp298Asn. The G allele was found to be associated with a lower BF, slower growth rate, and lower consumption (Burgos et al 2006, Bruun et al 2006, Meidtner et al 2006, Van den Maagdenberg et al 2008, Piorkowska et al 2010, Davoli et al 2012, Fontanesi et al 2013, Samoré and Fontanesi 2016).

Therefore, knowledge of the genetic structure of these breeds and their dynamics is crucial to plan appropriate strategies for the protection of native breeds and the conservation of their genetic diversity in the future.
The objective of this work was to study population dynamics and genetic structure in the Pampa Rocha, Celta, Bizaro Portuguese, Duroc, Iberian Extremeño and Iberian Andalusian porcine breeds, based on the IGF2 and MC4R genes, which determine meat characteristics and quality. These analyses allowed us to determine the degree of genetic variability, the genetic distance between the breeds, and presence or absence of consanguinity to help develop strategies against anthropogenic activities that hinder the conservation of the biodiversity of these breeds.

To protect native breeds, it is important to consider the specific characteristics of each one of them, along with the genetic divergence between them, and acknowledge the effect of exploitation exercised by man to achieve and maintain the necessary balance between the desired characteristics and their genetic specificity in a breed.

\section{MATERIAL AND METHODS}

\section{ANIMALS}

We studied 233 animals of six different breeds of pigs (58 Pampa Rocha, 35 Celta, 45 Bizaro Portuguese, 40 Duroc, 24 Iberian Extremeño, Spain, and 25 Iberian Andalusian, Spain). Six wild boars were used as control animals and several hunters supplied samples of frozen muscles from wild boars. Frozen muscle samples from Iberian pigs were obtained from COVAP (Pozoblanco, Spain) and CENSYRA (Badajoz, Spain). Dr. Carballo García (University of Vigo, Spain) provided frozen muscle samples from Celta pigs and hair samples from Bizaro Portuguese pigs. Hair samples from the Pampa Rocha pigs were obtained from animals belonging to the reproductive group of the Pig Production Unit of the South Regional Center of the Experimental Station of the Faculty of Agronomy (University of the Republic) located in Progreso, Canelones (Uruguay). Semen samples of the Duroc pigs were obtained from Agropecuaria OBANOS S.A. Marcilla (Spain).

The Bioethical Committee Certification has been obtained and all researchers who have collaborated in this work have the Technical Competence in Animal Health, Husbandry and Handling.

\section{DNA EXTRACTION}

DNA was extracted from muscle, semen, or hair follicles by using the Realpure Genomic DNA Extraction Kit ${ }^{1}$ and the GenomicPrep ${ }^{\mathrm{TM}}$ DNA isolation $\mathrm{kit}^{2}$ following the manufacturer's instructions. The concentration of DNA in the extract was determined by using a NanoDrop ${ }^{\mathrm{TM}}$

\footnotetext{
Durviz (Valencia, Spain).

Amersham Biosciences (Little Chalfont, United Kingdom).
} 
1000 spectrophotometer $^{3}$. DNA was extracted from all the samples reaching a DNA concentration of about $4 \times 10^{2}$ $\mathrm{ng} / \mu \mathrm{L}$ and diluted to a working concentration of $1 \mathrm{ng} / \mu \mathrm{L}$.

\section{GENOTYPING}

Genotyping for IGF2 and MC4R was performed by real-time PCR as described by Carrodeguas et al (2005), Burgos et al (2006 and 2012), Galve et al (2013) and Latorre et al (2016). The PCR reactions were carried out using an ABI-PRISM 7000 apparatus ${ }^{4}$.

For the IGF2 gene amplification, each assay contained $12.5 \mu \mathrm{L}$ of TaqMan Universal PCR Master Mix, 0.6 $\mu \mathrm{L}$ of 40x Assay Mix, $5 \mu \mathrm{L}$ of genomic DNA ( $1 \mathrm{ng} / \mu \mathrm{L})$ and double distilled $\mathrm{H}_{2} \mathrm{O}$ to $25 \mu \mathrm{L}$. PCR was carried out using an initial cycle of $10 \mathrm{~min}$ at $95^{\circ} \mathrm{C}$ followed by 45 cycles of $15 \mathrm{~s}$ at $92{ }^{\circ} \mathrm{C}$ and $1 \mathrm{~min}$ at $61{ }^{\circ} \mathrm{C}$. The primers used were IGF2F (AGCCAGGGACGAGCCT) and IGF2R (GAGGCCCGCGGACTC). The probes were IGF2V1 (CTAGGCTCGCAGCGC, labelled with the dye VIC) and IGF2M1 (CTAGGCTCACAGCGC, labelled with the dye FAM).

For the $M C 4 R$ gene, the PCR assay sets contained $12.5 \mu \mathrm{L}$ of TaqMan Universal PCR Master Mix, 0.6 $\mu \mathrm{L}$ of 40x Assay Mix, $5 \mu \mathrm{L}$ of genomic DNA (1 ng/ $\mu \mathrm{L}$ ) and double distilled $\mathrm{H}_{2} \mathrm{O}$ to $25 \mu \mathrm{L}$. PCR reaction was carried out using an initial cycle of $10 \mathrm{~min}$ at 95 ${ }^{\circ} \mathrm{C}$ followed by 50 cycles of $15 \mathrm{~s}$ at $92{ }^{\circ} \mathrm{C}$ and $1 \mathrm{~min}$ at $60{ }^{\circ} \mathrm{C}$. The primers used were PIGBRAIN-MC4RF (TGCTTCATGTCTCACTTTAATTTGTATCTCA) and PIGBRAIN-MC4RR (GGCTCCGGAGTGCATAAATCA). The probes were PIGBRAIN-MC4RV1, attached to VIC fluorescent label, (CATCATCGATCCCC) and PIGBRAIN-MC4RM1, attached to FAM fluorescent label, (CATCATCAATCCCC).

\section{STATISTICAL AND GENETIC ANALYSES}

The analysis of gene and genotypic frequencies, as well as the heterozygosity for each gene in each breed, was performed according to Nei (1978) by using the BIOSYS-2 program (Swofford et al 1997). The number of alleles per locus (A), allele frequencies, observed heterozygosity (Ho) and expected heterozygosity $(\mathrm{He})$ for genetic variation within local populations in the six porcine populations of this work have been estimated according to Hartl and Clark (1997) and Hedrick (2000).

We examined the total genetic diversity (HT), genetic diversity within populations (HS), genetic diversity among populations (DST), and genetic differentiation coefficient (GST) in genetic diversity within and among populations

\footnotetext{
3 Thermo Fischer Scientific, (Wilmington, DE, USA)

4 Thermo Fischer Scientific, (Wilmington, DE, USA).
}

(Weir and Cockerham 1984, Hedrick 2000, Culley et al 2002).

By using Wright's F-statistics (Wright 1978), the inbreeding coefficients between individuals within a population (Fis) and genetic differentiation between populations (Fst) were calculated.

The Fis coefficient is a measure of the deviation of the panmictic frequencies, in terms of excess or deficiency of heterozygotes, caused by the tendency for crosses to occur between related individuals; it is defined as the probability that two alleles in an individual are identical by descent with respect to the subpopulation. The value of this index varies between -1 and 1 . The negative values indicate an excess of heterozygotes, with respect to the Hardy-Weinberg equilibrium while positive values indicate a deficiency of heterozygotes (inbreeding). To evaluate whether the Fis values were significantly different from zero, a test $\chi^{2}=\mathrm{F} 2 \mathrm{~N}$ (k-1) was performed with $\mathrm{df}=[\mathrm{k}(\mathrm{k}-1)] / 2$, where $\mathrm{F}$ is the inbreeding coefficient, $\mathrm{N}$ is the sample size and $\mathrm{k}$ is the number of alleles (Li and Horvitz 1953).

Wright's Fst (Wright 1978) measures the effect of genetic subdivision or the reduction of heterozygosity in a population due to genetic drift; it is defined as the correlation of alleles of different individuals in the same population and varies between zero and one. When the estimate of Fst is 0.050 or less, it does not imply that genetic differentiation is negligible (Wright 1978). The zero value indicates panmixia or random matings, all subpopulations are in equilibrium and no genetic divergence occurs in the population. The value of one indicates complete isolation, an extreme subdivision of the population. To find out if the Fst values were significantly different from zero, we calculated $\chi^{2}=2 \mathrm{NFst}(\mathrm{k}-1)$ with $\mathrm{df}=[(\mathrm{k}-1)(\mathrm{s}-1)]$, where $\mathrm{N}$ is the sample size, $\mathrm{k}$ is the number of alleles, and $\mathrm{s}$ is the number of subpopulations, in this case, the number of breeds (Workman and Niswander 1970).

Gene flow and genetic distances were also calculated. Gene flow is the transfer of genetic material from one population to another (Nm) (Slatkin 1987) and genetic distances (Nei 1978) reflect the number of changes that have occurred since the separation of two populations and is appropriate when populations diverge because of drift and mutations. This measure was based on the "normalised identity", which expresses the probability that when choosing one allele at random from each of the two populations considered, these are identical (Weir 1996, Ryman and Leimar 2008). The Nei distances used were corrected for small sample sizes (Nei 1978).

\section{RESULTS}

The allelic and genotypic frequencies are indicated in table 1. For $I G F 2$, only Celta, Iberian Extremeño, and Iberian Andalusian populations showed significant deviations $(P \leq 0.05)$ in the Hardy-Weinberg (HW) equilibrium, which could indicate a trend of directed matings or selection 
in these populations. The other populations were in HW equilibrium $(P \geq 0.05)$. For $M C 4 R$, all populations were in HW equilibrium $(P \geq 0.05)$.

In total, two alleles per locus in the two analysed loci were identified in all populations. The number of polymorphic loci was estimated, considering that a locus was polymorphic only if the frequency of the most common allele was less than an arbitrary value, which was typically 0.99. Similarly, only the Pampa Rocha, Bizaro Portuguese, and Duroc populations displayed polymorphism in the IGF2 locus; this locus was considered non-polymorphic in the rest populations analysed. In contrast, all the analysed populations displayed polymorphism in the $M C 4 R$ locus, except for wild boar samples that allele $G$ was fixed.

The heterozygosity is indicated in table 2, in the IGF2 and $M C 4 R$ locus. The Celta, Iberian Extremeño and Iberian
Andalusian populations had the lowest average genetic diversity within the populations; that is, the lowest $\mathrm{He}$ and Ho heterozygosities.

The genetic diversity (D) between populations is presented in table 4, being the greatest estimated distance between the populations of Celta and Duroc.

It was also calculated the coefficient of genetic differentiation for all loci, obtaining a value of GST $=0.5027$, which indicated a genetic diversity of $50.27 \%$ among the populations and a genetic diversity of $49.73 \%$ within them.

\section{WRIGHT'S F STATISTICS}

The results obtained are shown in table 3 . A positive Fis was obtained only in the Duroc breed, although a very low value; the rest of breeds did not indicate consanguinity,

Table 1. Allelic and genotype frequencies for the $I G F 2$ and $M C 4 R$ genes analysed in the six pig breeds.

\begin{tabular}{|c|c|c|c|c|c|}
\hline \multirow{2}{*}{ Breed } & \multicolumn{2}{|c|}{ Allelic frequency } & \multicolumn{3}{|c|}{ Genotype frequency } \\
\hline & A & G & AA & $\mathrm{AG}$ & GG \\
\hline \multicolumn{6}{|c|}{$I G F 2$} \\
\hline Pampa Rocha & 0.01 & 0.99 & 0.00 & 0.02 & 0.98 \\
\hline Celta & 0.00 & $1.00^{\mathrm{a}}$ & 0.00 & 0.00 & $1.00^{\mathrm{a}}$ \\
\hline Bizaro Portuguese & 0.02 & 0.98 & 0.00 & 0.04 & 0.96 \\
\hline Duroc & 0.85 & 0.15 & 0.72 & 0.25 & 0.03 \\
\hline Iberian Extremeño & 0.00 & $1.00^{\mathrm{a}}$ & 0.00 & 0.00 & $1.00^{\mathrm{a}}$ \\
\hline Iberian Andalusian & 0.00 & $1.00^{\mathrm{a}}$ & 0.00 & 0.00 & $1.00^{\mathrm{a}}$ \\
\hline Wild boar & 0.00 & $1.00^{\mathrm{a}}$ & 0.00 & 0.00 & $1.00^{\mathrm{a}}$ \\
\hline \multicolumn{6}{|c|}{$M C 4 R$} \\
\hline Pampa Rocha & 0.59 & 0.41 & 0.31 & 0.55 & 0.14 \\
\hline Celta & 0.03 & 0.97 & 0.00 & 0.06 & 0.94 \\
\hline Bizaro Portuguese & 0.14 & 0.86 & 0.00 & 0.29 & 0.71 \\
\hline Duroc & 0.57 & 0.43 & 0.33 & 0.50 & 0.17 \\
\hline Iberian Extremeño & 0.08 & 0.92 & 0.00 & 0.17 & 0.83 \\
\hline Iberian Andalusian & 0.04 & 0.96 & 0.00 & 0.08 & 0.92 \\
\hline Wild boar & 0.00 & $1.00^{\mathrm{a}}$ & 0.00 & 0.00 & $1.00^{\mathrm{a}}$ \\
\hline
\end{tabular}

${ }^{a}$ For the $I G F 2$ gene only the Celta, Iberian Extremeño, and Iberian Andalusian population groups showed significant deviations $(P \leq 0.05)$ for the Hardy-Weinberg equilibrium analysis (HW). The other populations are in equilibrium of HW $(P \geq 0.05)$.

For the $M C 4 R$ gene all populations are in HW equilibrium $(P \geq 0.05)$.

Table 2. Average expected and observed heterozigosity, on the loci analysed in the six populations studied.

\begin{tabular}{lcccc}
\hline & He & Ho & $\mathrm{P}(0.95)^{\mathrm{a}}$ & $\mathrm{P}(0.99)^{\mathrm{a}}$ \\
\hline Pampa Rocha & 0.2511 & 0.2845 & 0.5000 & 0.5000 \\
Celta & 0.0278 & 0.0286 & 0.0000 & 0.5000 \\
Bizaro Portuguese & 0.1453 & 0.1667 & 0.5000 & 1.0000 \\
Duroc & 0.3719 & 0.3750 & 1.0000 & 1.0000 \\
Iberian Extremeño & 0.0764 & 0.0833 & 0.5000 & 0.5000 \\
Iberian Andalusian & 0.0384 & 0.0400 & 0.0000 & 0.5000 \\
\hline
\end{tabular}

aThreshold 95\%, and 99\% indicates that the locus is considered polymorphic if the most frequent allele does not exceed 95\% or 99\%, respectively. 
with negative Fis values, Fis average values for each locus was negative for both loci.

The estimated values for Fst, according to Weir and Cockerham (1984), are indicated in table 5. The values obtained suggested that most of the genetic diversity was found within the populations.

A value of $\mathrm{Nm}>1$ indicates high gene flow between the populations (Wright 1969). The values of the genetic flow among the populations are shown in table 6 . The genetic distances of Nei (1978) are presented in table 7.
Table 3. Fis values for each of the six porcine populations analysed.

\begin{tabular}{lcl}
\hline \multicolumn{1}{c}{ Population } & \multicolumn{1}{c}{ Fis } & \multicolumn{1}{c}{ (IC 95 \%) } \\
\hline Pampa Rocha & -0.12433 & $(-0.39877-0.10882)$ \\
Celta & -0.01493 & $(-0.06250--0.00000)$ \\
Bizaro Portuguese & -0.13597 & $(-0.22401--0.06344)$ \\
Duroc & 0.00426 & $(-0.24877-0.25072)$ \\
Iberian Extremeño & -0.06977 & $(-0.17949-0.00000)$ \\
Iberian Andalusian & -0.02128 & $(-0.09091-0.00000)$ \\
\hline
\end{tabular}

Table 4. Genetic diversity (D) between each pair of populations analysed.

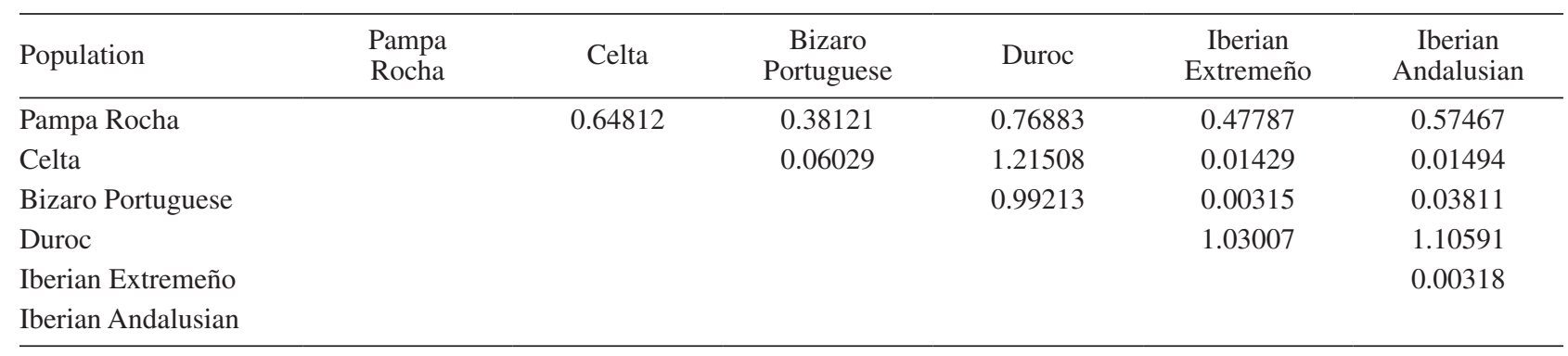

Table 5. Fst values according to Weir and Cockerham (1984) for each pair of populations studied.

\begin{tabular}{|c|c|c|c|c|c|c|}
\hline Population & $\begin{array}{l}\text { Pampa } \\
\text { Rocha }\end{array}$ & Celta & $\begin{array}{c}\text { Bizaro } \\
\text { Portuguese }\end{array}$ & Duroc & $\begin{array}{c}\text { Iberian } \\
\text { Extremeño }\end{array}$ & $\begin{array}{c}\text { Iberian } \\
\text { Andalusian }\end{array}$ \\
\hline Pampa Rocha & & 0.47697 & 0.31696 & 0.53645 & 0.37990 & 0.43711 \\
\hline Celta & & & 0.05851 & 0.70331 & 0.01419 & 0 \\
\hline Bizaro Portuguese & & & & 0.62921 & 0.00314 & 0.03740 \\
\hline Duroc & & & & & 0.64302 & 0.66909 \\
\hline Iberian Extremeño & & & & & & 0 \\
\hline
\end{tabular}

Table 6. Gene flow Nm (Wright, 1969) between each pair of populations analysed.

\begin{tabular}{|c|c|c|c|c|c|c|}
\hline Population & $\begin{array}{l}\text { Pampa } \\
\text { Rocha }\end{array}$ & Celta & $\begin{array}{c}\text { Bizaro } \\
\text { Portuguese }\end{array}$ & Duroc & $\begin{array}{c}\text { Iberian } \\
\text { Extremeño }\end{array}$ & $\begin{array}{c}\text { Iberian } \\
\text { Andalusian }\end{array}$ \\
\hline Pampa Rocha & & 0.27 & 0.54 & 0.22 & 0.41 & 0.32 \\
\hline Celta & & & 4.02 & 0.11 & 17.37 & $\mathrm{a}$ \\
\hline Bizaro Portuguese & & & & 0.15 & 79.36 & 6.44 \\
\hline Duroc & & & & & 0.14 & 0.12 \\
\hline Iberian Extremeño & & & & & & a \\
\hline
\end{tabular}

${ }^{a}$ The gene flow between these populations has not been estimated, to reach values Fst $\leq 0$, between these indicated populations.

Table 7. Genetic distances of Nei (1978) among the six porcine populations studied.

\begin{tabular}{lcccccc}
\hline Population & $\begin{array}{c}\text { Pampa } \\
\text { Rocha }\end{array}$ & Celta & $\begin{array}{c}\text { Bizaro } \\
\text { Portuguese }\end{array}$ & Duroc & $\begin{array}{c}\text { Iberian } \\
\text { Extremeño }\end{array}$ & $\begin{array}{c}\text { Iberian } \\
\text { Andalusian }\end{array}$ \\
\hline Pampa Rocha (58) & 0.000 & 0.189 & 0.125 & 0.816 & 0.156 & 0.182 \\
Celta (35) & 0.189 & 0.000 & 0.004 & 1.123 & 0.000 & 0.001 \\
Bizaro Portuguese (45) & 0.125 & 0.004 & 0.000 & 0.989 & 0.000 & 0.003 \\
Duroc (30) & 0.816 & 1.123 & 0.989 & 0.000 & 1.080 & 1.114 \\
Iberian Extremeño (24) & 0.156 & 0.000 & 0.000 & 1.080 & 0.000 & 0.000 \\
Iberian Andalusian (25) & 0.182 & 0.001 & 0.003 & 1.114 & 0.000 & 0.000 \\
\hline
\end{tabular}




\section{DISCUSSION}

During the process of selection, genetic variability can decrease compared with that of the original population. This decrease in genetic variability is a consequence of the selection process that involves the criteria and methods of selection with any degree of sophistication or use of current advanced techniques (Meffe 1986, Leberg 1992, Wellmann and Bennewitz 2019).

From the results obtained in this work, it was deduced that each analysed locus presented a different polymorphism in each porcine breed studied. In the IGF2 locus (table 1), only the Bizaro Portuguese and Duroc populations presented interesting polymorphisms with a frequency of the $\mathrm{G}$ allele (0.98) much higher than the A allele (0.02) in the Bizaro Portuguese, unlike that the A allele (0.85) occurred at a higher frequency than the $\mathrm{G}$ allele (0.15) in Duroc; the A allele was observed in the Pampa Rocha population too but a very low frequency (0.01), similar to the frequency obtained by Burgos et al (2019) in this breed. In this locus, our results are very similar to those obtained by Fernandez et al (2017) for the Bizaro Portuguese breed ( $\mathrm{G}$ allele with 0.99 and A allele with 0.01) and Burgos et al 2019 (G allele with 0.981 and A allele with 0.019). The rest of the populations do not have a frequency of A allele, as the $G$ allele was fixed for the animals studied.

Fassa et al (2015) confirmed the greater effect of the $\mathrm{A}$ allele on $\mathrm{BF}$ and feed conversion, reporting that those pigs with the A allele had $1.8 \mathrm{~mm}$ less fat and better-feed conversion (they consumed $0.3 \mathrm{~kg}$ less of feed per $\mathrm{kg}$ of pork produced).

Oczkowicz et al (2009) reported that the frequency of the A allele was higher in the breeds or lines subjected to greater selection pressure for leanness and that the A allele increased the average daily weight gain and decreased consumption in Landrace populations. Fontanesi et al $(2010,2012)$ analysed a population of Large White Italian animals and, using as a registry of breeding values for BF, found that the animals with the highest expected breeding value for this character had a lower frequency of the $\mathrm{G}$ allele (0.38), whereas the animals with the lowest expected breeding value for BF had a higher frequency of the $\mathrm{G}$ allele (0.72).

In the $M C 4 R$ locus, our results indicate that the populations of the Pampa Rocha and Duroc breeds have higher frequencies of the A allele ( 0.59 and 0.57 , respectively), although they are values close to the $\mathrm{G}$ allele frequencies (0.41 and 0.43); however, their genetic structure is optimised for the objectives of higher performance, lower BF, and greater lean weight. Ovilo et al (2006), associated the identified missense mutation (Asp298Asn) located in a highly conserved region of this gene with backfat depth, feed intake and growth rate in different porcine lines. Our results differ slightly from those obtained by Klimenko et al (2014), who found a higher frequency of G allele (0.71) compared with the A allele (0.29) in other pig breeds. It should be noted that Park et al (2002) and Fassa et al (2015) did not find significant differences between $M C 4 R$ genotypes and production characteristics, except for the wild boar samples.

Population genetics is the discipline studying the genetic diversity and structuring of populations and the processes governing them, including changes in allele frequencies over time, and further embracing the aspects of quantitative genetics (Hartl and Clark 1997, Hedrick 2000). Our main objective was to determine the genetic variability of these pig populations because the use of genetic data in the establishment of conservation units is of great importance. According to Erwin (1991), it is necessary to recover and maintain processes within the species itself, instead of conserving only distinctive phenotypes, therefore, the utility of the genetic data is magnified. This argument is based on the fact that the functioning of microevolutionary processes requires intraspecific genetic variability that, although not an innovative perspective in conservation, was already identified in the 1970s (Frankel 1974) and has been strengthened since then by evolutionary biologists (Templeton 1986).

A good measure of genetic variation is the average frequency of heterozygous individuals per locus or, similarly, the heterozygosity of the population (Fontdevila and Moya 1999). In our work, the observed heterozygosities (Ho) were higher than those expected (He) (table 2), which was an indication that the heterozygosity of all the studied breeds was good and did not show consanguinity. Indeed, Fis values were mostly negative (Fis negative values represent the absence of inbreeding or consanguinity) (table 3) except for the Duroc population which, although a positive value, was a very low value. According to Hartl (2000) positive magnitudes of the Fis, Fis is considered low if Fis $=0-0.05$, average Fis $=0.06-0.15$, high Fis $=0.16-0.25$ and very high Fis $>0.25$.

The values obtained in our work for genetic diversity (D) among the populations range from the lowest estimated value, corresponding to the Bizaro Portuguese and Iberian Extremeño populations (table 4), to the highest value obtained, between the Duroc and Celta. As reported by Ryman and Leimar (2008), the effect of the mutation is small on the GST value in the early stages of divergence of populations, but it is unclear how long it has been since the separation of ancestral populations and whether the mutation may have affected heterozygosity. It is possible to think that the effect of the mutation is very small on that genetic diversity and that selection has been the most important effect on diversity. It is interesting to see how the genetic diversity obtained in our populations reaches a value of GST $=0.5027$, which indicated a genetic diversity of $50.27 \%$ among the populations and a genetic diversity of $49.73 \%$ within them. These are expected results since that genetic diversity will be greater between different populations and breeds than within each population; 
however, these results indicate that at one time there were genetic exchanges between all of them.

Similarly, for the estimated Fst (table 5), which measure the genetic differentiation between populations, the lowest value obtained is again between the Bizaro Portuguese and Iberian Extremeño (0.00314) and the highest value between the Celta and Duroc populations (0.70331). Regarding gene flow $(\mathrm{Nm})$ or exchange of genes (table 6) that has occurred in the history in these populations, the highest value (79.36) was obtained between the Bizaro Portuguese and Iberian Extremeño, therefore, when having a greater gene flow, a lower genetic distance has been obtained (table 7) between both populations (0.00). In contrast, the lowest gene flow $(\mathrm{Nm})$ corresponded to the Duroc and Celtic populations $(0.11)$, along with the greatest genetic distance between these same populations $(1,123)$.

Genomic selection is becoming a reality in livestock species. As indicated by Samoré and Fontanesi (2016), the applications of genomic selection are opening new opportunities in pig breeding. It is expected that the complete sequencing data will provide the best prediction accuracy since all causal mutations underlying a trait can be included (Zhang et al 2018). But sequencing is still too expensive for implementation in a large number of animals. Therefore, low-coverage DNA sequence fragment analysis strategies reduce costs and are well accepted.

In conclusion, it is very interesting to note that in our results the Pampa Rocha and Bizaro Portuguese autochthonous breeds present a certain frequency of the beneficial A allele at the IGF2 locus, although with a much lower frequency than that of the Duroc breed.

Moreover, in the Celta, Iberian Extremeño and Iberian Andalusian populations the imbalance observed for the alleles of the IGF2 locus can be considered, in its broadest sense, to be due to selection, that is, that there had directed crosses at some point in their history. Finally, it is very pleasing to verify that the heterozygosity in the $M C 4 R$ locus is high in all the analysed populations, which is indicating a good genetic "health" in all of them including the autochthonous breeds, knowing that they have started from a smaller number in their population components. These results could help breeders to manage their livestock and, at the same time, they highlight the need to continue controlling their populations through genetic analyses to avoid the loss of genetic variability and the presence of inbreeding at all times.

\section{REFERENCES}

Andersson L, Haley CS, Ellegren H, Knott SA, Johansson M, et al. 1994. Genetic-mapping of quantitative trait loci for growth and fatness in pigs. Science 263, 1771-1774.

Avise JC. 1994. Molecular Markers, Natural History and Evolution. Chapman \& Hall, NY. USA.

Azevedo CF, Nascimento M, Silva FF, Resende MDV, Lopes PS, et al. 2015. Comparison of dimensionality reduction methods to predict genomic breeding values for carcass traits in pigs. Genet Mol Res $14,12217-12227$.
Burgos C, Carrodeguas JA, Moreno C, Altarriba J, Tarrafeta L, et al. 2006. Allelic incidence in several pig breeds of a missense variant of pig melanocortin-4 receptor $(M C 4 R)$ gene associated with carcass and productive traits; its relation to IGF2 genotype. Meat Sci 73, 144-150.

Burgos C, Galve A, Moreno C, Altarriba J, Reina L, et al. 2012. The effects of two alleles of $I G F 2$ on fat content in pig carcasses and pork. Meat Sci 90, 309-313.

Burgos C, Llambí S, Hidalgo G, Montenegro M, Arruga MV, et al. 2019. Marcadores de selección en cerdos Pampa Rocha: comparación con razas autóctonas de España y Portugal. Rev MVZ Cordoba 24, 7198-7202.

Bruun CS, Jørgensen CB, Nielsen VH, Andersson L, Fredholm M. 2006. Evaluation of the porcine melanocortin 4 receptor $(M C 4 R)$ gene as a positional candidate for a fatness QTL in a cross between Landrace and Hampshire. Anim Genet 37, 359-362.

Carrodeguas JA, Burgos C, Moreno C, Sánchez AC, Ventanas S, et al. 2005. Incidence in diverse pig populations of an IGF2 mutation with potential influence on meat quality and quantity: an assay base done real time PCR (RT-PCR). Meat Sci 71, 577-582.

Cockerham CC. 1973. Analysis of gene frequencies. Evolution 23, 72-84.

Culley TM, Wallace LE, Gengler-Nowak KM, Crawford DJ. 2002. A comparison of two methods of calculating GST, a genetic measure of population differentiation. Am J Bot 89, 460-465.

Davoli R, Braglia S, Valastro V, Annaratone C, Comella M, et al. 2012. Analysis of $M C 4 R$ polymorphism in Italian Large White and Italian Duroc pigs: association with carcass traits. Meat Sci 90, 887-892.

De Campos CF, Lopes MS, Silva FF, Veroneze R, Knol EF, et al. 2015. Genomic selection for boar taint compounds and carcass traits in a commercial pig population. Livest Sci 174, 10-17.

Erwin TL. 1991. An evolutionary basis for conservation strategies. Sciences 253, 750-752.

Estellé J, Mercadé A, Noguera JL, Perez-Enciso M, Ovilo C, et al. 2005. Effect of the porcine IGF2 intron3-G3072A substitution in an outbred Large White population and in Iberian x Landrace cross. J Anim Sci 83, 2723-2728.

Fassa VB, Carden TR, Marini SJ, Lett AD, Lloveras MR, et al. (2015). Análisis de los efectos de cinco genes (IGF2, CTSD, TBC1D1, $M C 4 R$ y $F A B P 3$ ) sobre la conversión alimenticia, la velocidad de crecimiento y el contenido de grasa subcutánea en cerdos de la raza Landrace. RIA Rev Investig Agropecu 41, 282-282.

Fernández AI, Muñoz M, García F, Núñez Y, Geracci C, et al. 2017. Distribution of polymorphisms in major and candidate genes for productive and domestication-related traits in European local pig breeds. ISAC, Zenodo. 36th International Society for Animal Genetics Conference, Dublin, Ireland.

Fisher RA. 1930. The Genetical Theory of Natural Selection. Clarendon Press, Oxford, UK.

Fontdevila A, Moya A. 1999. Introducción a la genética de poblaciones. Editorial Síntesis SA, Madrid, España.

Fontanesi L, Buttazzoni L, Galimberti G, Calò DG, Scotti E, et al. 2013. Association between melanocortin 4 receptor $(M C 4 R)$ gene haplotypes and carcass and production traits in italian large white pigs evaluated with a selective genotyping approach. Livest Sci 157, 48-56.

Fontanesi L, Colombo M, Tognazzi L, Scotti E, Buttazzoni L, et al. 2011. The porcine TBC1D1 gene: mapping, SNP identification, and association study with meat, carcass and production traits in Italian heavy pigs. Mol Biol Reports 38, 1425-1431.

Fontanesi L, Galimberti G, Caló GD, Fronza R, Martelli PL, et al. 2012. Identification and association analysis of several hundred single nucleotide polymorphisms within candidate genes for back fat thickness in Italian Large White pigs using a selective genotyping approach. J Anim Sci 90, 2450-2464.

Fontanesi L, Speroni C, Buttazzoni L, Scotti E, Dall`Olio S, et al. 2010. The insulin-like growth factor 2 (IGF2) gene intron3-g.3072G $>$ A polymorphism is not the only Sus scrofa chromosome 2 p mutation affecting meat production and carcass traits in pigs: Evidence from the effects of a cathepsin D (CTSD) gene polymorphism. J Anim Sci 88, 2235-2245. 
Frankel OH. 1974. Genetic conservation: our evolutionary responsibility. Genetics 78, 53-65.

Galve A, Burgos C, Varona L, Carrodeguas JA, López-Buesa P. 2013. Allelic frequencies of PRKAG3 in several pig breeds and its technological consequences on a Duroc 9 Landrace-Large White cross. J Anim Breed Genet 130, 382-393.

González-Sarabia AA, Lemus-Flores C, Mejía-Martínez K, RodríguezCarpena JG, Orozco-Benítez MG. 2011. Diversidad genética en cerdos criollos mexicanos con genes candidatos asociados a características productivas. Pesq Agropec Bras 46, 44-50.

Haldane JBS. 1932. The Causes of Evolution. Longmans and Green, London, UK.

Hartl DL. 2000. A Primer of Population Genetics. $3^{\text {rd }}$ ed. Sinauer Associates, Sunderland, MA, USA.

Hartl DL, Clark AG. 1997. Principles of Population Genetics. Sinauer Associates Inc. Publishers, Sunderland, MA, USA.

Hedrick PW. 2000. Genetics of Populations. $2^{\text {nd }}$ ed. Jones and Bartlett, Boston. MA, USA.

Kim KS, Larsen N, Short T, Plastow G, Rothschild MF. 2000. A missense variant of the melanocortin-4-receptor $(M C 4 R)$ gene is associated with fatness, growth, and feed intake traits. Mam Genome 11, 131-135.

Klimenko A, Usatov A, Getmantseva L, Kolosov Y, Tretyakova O, et al. 2014. Effects of melanocortin-4 receptor gene on growth and meat traits in PIGS raised in Russia. Am J Agric Biol Sci 9, 232-237.

Krashes MJ, Lowell BB, Garfield AS. 2016. Melanocortin-4 receptor-regulated energy homeostasis. Nat Neurosci 19, 206-219.

Latorre P, Burgos C, Hidalgo J, Varona L, Carrodeguas JA, et al. 2016. c.A2456C-substitution in Pck1 changes the enzyme kinetic and functional properties modifying fat distribution in pigs. Sci Rep 6, 19617.

Leberg PL. 1992. Effects of population bottlenecks on genetics diversity as measured by allozyme electrophoresis. Evolution 46, 477-494.

Lemus-Flores C, Ulloa-Arvizu R, Ramos-Kuri M, Estrada FJ, Alonso RA. 2001. Genetic analysis of Mexican hairless pig populations. $J$ Anim Sci 79, 3021-3026.

Li CC, Horvitz DG. 1953. Some methods of estimating the inbreeding coefficient. Am J Hum Genet 5, 107-117.

Meffe GK. 1986. Conservation genetics and the management of endangered fishes. Fisheries 11, 14-23.

Meidtner K, Wermter AK, Hinney A, Remschmidt H, Hebebrand J, et al. 2006. Association of the melanocortin 4 receptor with feed intake and daily gain in F2 Mangalitsa x Piétrain pigs. Anim Genet 37, 245-247.

Nei M. 1978. Estimation of average heterozygosity and genetic distance from a small number of individuals. Genetics 89, 583-590.

Oczkowicz M, Tyra M, Walinowicz K, Rózycki M, Rejduch B. 2009. Known mutation (A3072G) in intron 3 of the IGF2 gene is associated with growth and carcass composition in Polish pig breeds. J Appl Genet 50, 257-259.

Oczkowicz M, Tyra M, Walinowicz K, Ropka-Molik K, Mucha A, et al. 2012. Effect of IGF2 intron3-g. 3072G $>$ A on intramuscular fat (IMF) content in pigs raised in Poland. Livest Sci 149, 301-304.

Óvilo C, Fernández A, Rodríguez MC, Nieto M, Silio L. 2006. Association of $M C 4 R$ gene variants with growth, fatness, carcass composition and meat and fat quality traits in heavy pigs. Meat Sci 73, 42-47.
Park HB, Carlborg Ö, Marklund S, Andersson L. 2002. Melanocortin-4 receptor $(\mathrm{MC} 4 \mathrm{R})$ genotypes have no major effect on fatness in a Large White $\times$ Wild Boar intercross. Anim Genet 33, 155-157.

Phillips JD, Gillis DJ, Hanner DJ. 2019. Incomplete estimates of genetic diversity within species: Implications for DNA barcoding. Ecol Evol 9, 2996-3010.

Piórkowska K, Tyra M, Rogoz M, Ropka-Molik K, Oczkowicz M, et al. 2010. Association of the melanocortin-4 receptor $(M C 4 R)$ with feed intake, growth, fatness and carcass composition in pigs raised in Poland. Meat Sci 85, 297-301.

Ryman N, Leimar O. 2008. Effect of mutation on genetic differentiation among nonequilibrium populations. Evolution 62, 2250-2259.

Samoré AB, Buttazzoni L, Gallo M, Russo V, Fontanesi L. 2015. Genomic selection in a pig population including information from slaughtered full sibs of boars within a sib testing program. Animal 9, 750-759.

Samoré AB, Fontanesi L. 2016. Genomic selection in pigs: state of the art and perspectives. Ital J Anim Sci 15, 211-232.

Shen WJ, Yao T, Kong X, Williams KW, Liu T. 2017. Melanocortin neurons: Multiple routes to regulation of metabolism. Biochim Biophys Acta 1863, 2477-2485.

Slatkin M. 1987. Gene flow and the geographic structure of natural populations. Science 236, 787-792.

Stearns S. 1992. The Evolution of Life Histories. Oxford University Press, London, UK.

Swofford DL, Selander RB, Black WC. 1997. BIOSYS-2: A Computer Program for the Analysis of Allelic Variation in Genetics. University of Illinois and Fort Collins, CO, Colorado State University, UrbanaChampaign, Il, USA.

Templeton AR. 1986. Further comments on the statistical analysis of DNA-DNA hybridization data. Mol Biol Evol 3, 290-298.

Van den Maagdenberg K, Stinckens A, Claeys E, Buys N, De Smet S. 2008. Effect of the insulin-like growth factor-II and RYR1 genotype in pigs on carcass and meat quality traits. Meat Sci 80, 293-303.

Van Laere AS, Nguyen M, Braunschweig M, Nezer C, Collete C, et al. 2003. A regulatory mutation in $I G F 2$ causes a major QTL effect on muscle growth in the pig. Nature 425, 832-836.

Weir BS. 1996. Genetic data analysis II. Sinauer Associates, Inc. Publishers, Sunderland, MA, USA.

Weir BS, Cockerham CC. 1984. Estimating F-Statistics for the Analysis of Population-Structure. Evolution 38, 1358-1370.

Wellmann R, Bennewitz J. 2019. Key Genetic Parameters for Population Management. Front Genet 10, 1-20.

Workman PL, Niswander JD. 1970. Population studies on southwestern Indian tribes,II: Local genetic differentiation in the Papago. Am J Hum Genet 22, 24-49.

Wright S. 1969. Evolution and the genetics of populations. University of Chicago Press. Chicago (Illinois) USA.

Wright S. 1978. Evolution and the genetics of populations, vol. 4. Variability within and among natural populations. University of Chicago Press, Chicago (Illinois) USA.

Zhang Ch, Kemp RA, Stothard P, Wang Z, Boddicker N, et al. 2018. Genomic evaluation of feed efficiency component traits in Duroc pigs using $80 \mathrm{~K}, 650 \mathrm{~K}$ and whole genome sequence variants. Genet Sel Evol 50, 14. 